\title{
Existing Status of Acacia Woodlands in Central Saudi Arabia: A Case Study in Hawtat Bani Tamim and Al Duwadmi
}

\author{
Thobayet Safar Alshahrani* \\ Plant Production Department College of Food and Agriculture Sciences King Saud University P.O. Box 2460, Riyadh 11451, \\ Saudi Arabia \\ *For correspondence: talshahrani@ksu.edu.sa; thobayet@yahoo.com \\ Received 27 October 2020; Accepted 02 January 2021; Published 16 April 2021
}

\begin{abstract}
Acacia woodlands are ecologically important and it is necessary to understand its structures and dynamics to develop sustainable conservation strategies. This study aimed to provide baseline information on the composition and growth of Acacia woodlands in the Hawtat Bani Tamim and Al Duwadmi regions of central Saudi Arabia. Height, diameter at breast height, crown diameter, seedling density, and soil seed bank content of Acacia tree species were characterized for 27 remote, circular, 0.1-ha plots in both study areas. At Hawtat Bani Tamim, Acacia raddiana, A. tortilis, and A. ehrenbergiana accounted for $45.53,37.5$ and $16.96 \%$ of all species present there. Most DBH were in the $6-10 \mathrm{~cm}$ class. A. raddiana was the main species in most diameter classes. Most trees were 4.1-5.0 m tall and A. raddiana predominated in this height class. Acacia ehrenbergiana had $92.63 \%$ damaged seeds. At Al Duwadmi, A. raddiana represented $78.99 \%$ of all Acacia trees there. A. gerrardii and A. tortilis accounted for 11.93 and $9.07 \%$ of the species there, respectively. Most of the DBH values were in the 6-10 cm and 11-15 cm classes, and A. tortilis and A. raddiana were abundant in both classes. Most trees were in the 4.1-5 $\mathrm{m}$ height class, which was dominated by $A$. raddiana. A. ehrenbergiana had $88.26 \%$ damaged seeds. In both areas, there was a gradual decline in the number of trees in DBH classes $>35 \mathrm{~cm}$. The Acacia species in the two areas showed a fair regeneration status. There were more seedlings than saplings and fewer saplings than trees. This baseline study could contribute towards future sustainability planning initiatives after other assessment studies have been conducted to identify changes in the Acacia woodlands of this region. (C) 2021 Friends Science Publishers
\end{abstract}

Key words: Baseline; Crown diameter; DBH; Sapling; Seedling; Soil seed bank

\section{Introduction}

In Saudi Arabia, Acacia tree species are naturally distributed in small, low-density populations. Saudi Arabia is located in a desert belt region characterized by variable but very low amounts of rainfall and high temperatures. The Acacia woodlands in Saudi Arabia are undergoing intense grazing and logging for firewood and charcoal. A. tortilis is the preferred national fuelwood source. The level at which this species is being exploited far surpasses its ability to regenerate and meet the escalating demands of the local communities (Al-Abdulkader et al. 2004). Perturbations such as overgrazing and socioeconomic changes have caused severe rangeland and other forms of degradation in the interior of Saudi Arabia (Al-Rowaily et al. 2018). However, Acacia trees are palatable to herbivores and heavy browsing on them reduces their canopy cover and density (Noumi et al. 2010; Al-Rowaily et al. 2012).

Extreme environmental conditions such as drought impede plant growth and survival. Nevertheless, Acacia species can survive and even thrive under such conditions. In desert ecosystems, Acacia trees improve soil nutrient status (Munzbergova and Ward 2002) and soil moisture (Ross and Burt 2015). Despite hindrances such as drought and temperature, root nodule bacteria nonetheless associate with Acacia species in central Saudi Arabia (Alshaharani and Shetta 2015). This mutualism may enhance soil fertility in arid and semiarid habitats (Zahran 1999). De Boever (2015) reported that in Tunisia, a single $A$. raddiana tree improved soil water availability in the top $40 \mathrm{~cm}$ soil layer by $\leq 175 \%$ inside and outside the canopy.

A baseline or reference study evaluates degradation by comparison either with a previous state (FAO 2011) or with a contemporaneous reference condition (Thompson et al. 2013). In each case, the reference context must be derived from the same biome type in the same climate zone. The use of indicators such as shoot growth, soil seed banks, seedling abundance, or age structure of common woody plant species provides information regarding forest recovery in response to disturbances. Analyzing seedlings and young tree 
communities helps predict future forest dynamics (Ghazoul et al. 2015). A tree diameter class provides valuable forestrelated information. A high frequency of individuals in the pole- and small-tree diameter classes (diameter at breast height $(\mathrm{DBH})<20 \mathrm{~cm})$ indicates that forests are adversely affected by human perturbations (Nyland 2017). Puri et al. (2013) used baseline data to assess standing volume and periodic mean annual increment in four forests between 2005 and 2010. While the increment was excellent in two of the forests, the other two required regrowth.

The remarkable benefits of Acacia in fragile ecosystems such as deserts must be maintained by conserving trees. To develop sustainable Acacia forest conservation strategies, it is necessary to understand its population dynamics. As Acacia trees are ecologically important in their ecosystems, the aim of the current study was to explore the status of the Acacia woodlands in central Saudi Arabia. There were no prior baseline studies describing their structure, composition, or regeneration state. However, the current study was conducted to establish the current Acacia woodlands state. This information may help plan forest conservation and sustainability by monitoring changes in the Acacia woodlands using the findings of the current study as a frame of reference.

\section{Materials and Methods}

\section{Study areas}

The present study was conducted in 2013 at two heterogeneous areas (Table 1) spaced $350 \mathrm{~km}$ apart, namely Al Duwadmi (15 plots; sandy clay soil) and Hawtat Bani Tamim (12 plots; sandy loam soil). The two areas were open, unprotected public lands. They were selected according to their natural Acacia distributions and densities. The Acacia species in Saudi Arabia were described in details by Collenette (1999) and Chaudhary (1999).

\section{Sampling of woody species}

Woody species were sampled in circular plots ( $0.1 \mathrm{ha})$ with plastic ropes. There were three replicates per location. One end of the rope was fixed to a peg at the center of the plot while the other was connected to a freely moving peg used to draw circles $17.8 \mathrm{~m}$ in radius. The trees and seedlings within the circles were counted and measured as described below:

Measurement of tree characteristics: Tree diameter was measured with a tree caliper at $1.3 \mathrm{~m}$ above ground level. To determine total tree height, a telescoping measuring pole was pushed through the crown and the height was recorded when the pole reached the plane of the treetop. Smaller trees $(<1.30 \mathrm{~m}$ tall) were scored as seedlings. Trees whose height was $>1.3 \mathrm{~m}$ but $<2 \mathrm{~m}$ were rated saplings. Trees with multiple leaders forking above the $\mathrm{DBH}$ were considered to have single stems. Crown diameter was measured horizontally with a telescoping measuring pole in two fixed perpendicular directions. For groups of trees, crown diameters were measured for each individual tree.

Soil seed bank determination: Five soil samples were collected per plot to determine soil seed bank content. One sample was taken at the center of the plot while the other four were collected at random locations under the trees in the plot. A metal frame $(0.5 \mathrm{~m} \times 0.5 \mathrm{~m})$ was placed under each sampled tree in the plot and a soil sample was collected at $5 \mathrm{~cm}$ depth and placed in a cloth bag. Soil samples were sieved through 3,5 and $8 \mathrm{~mm}$ screens to remove stones, soil, and other debris. The seeds from each sample were counted and examined under a magnifying glass and categorized as intact or damaged.

\section{Statistical analysis}

As the two areas differed in topography and soil type, the data were analyzed separately for each of them. The sample sizes between areas were unequal. Thus, the MIXED procedure in SAS (v. 9.1; SAS Institute Inc., Cary, NC, USA) was used to conduct statistical analyses and estimate the variance. To identify differences between means, Duncan's new multiple range test was applied at $P<0.05$.

Diameter distribution was plotted on a bar graph constructed using species frequency percentages (\%; y-axis) categorized into eight diameter classes (x-axis): The DBH classes were $2-3 \mathrm{~cm}, 6-10 \mathrm{~cm}, 11-15 \mathrm{~cm}, 16-20 \mathrm{~cm}, 21-25$ $\mathrm{cm}, 26-30 \mathrm{~cm}, 31-35 \mathrm{~cm}$, and $36-40 \mathrm{~cm}$. The frequency of each species in each diameter class was plotted on a bar graph constructed using the numbers of stems per species (y-axis) categorized in the eight aforementioned diameter classes (x-axis). The Acacia species height distributions were plotted on a bar graph constructed using the frequency percentage $(\%)$ of each species (y-axis) categorized in seven height classes (x-axis), namely, 2-3 m, 3.1-4 m, 4.1-5 m, 5.1-6 m, 6.1-7 m, 7.1-8 m, and 8.1-9 $\mathrm{m}$. The frequency of each species in each height class was plotted on a bar graph constructed using the frequency percentage (\%) of each species (y-axis) categorized in the aforementioned seven height classes (x-axis). The regeneration status of each Acacia species was determined based on the number of individuals at the seedling, sapling, and tree stages (Khumbongmayum et al. 2006).

\section{Results}

\section{Acacia growth in Hawtat Bani Tamim}

The most common Acacia species in Hawtat Bani Tamim was A. raddiana (45.53\%) followed by A. tortilis $(37.50 \%)$ and $A$. ehrenbergiana (16.96\%). Table 2 shows the growth parameters of the Acacia species in Hawtat Bani Tamim. Maximum height, $\mathrm{DBH}$, and crown diameter of $A$. raddiana at Wadi Aunthur were $5.38 \mathrm{~m}, 10.22 \mathrm{~cm}$, and $6.44 \mathrm{~m}$, respectively. A. raddiana $\mathrm{DBH}$ was greatest at $\mathrm{El}$ Hareeq 
Table 1: Coordinates of the two study areas in central Saudi Arabia

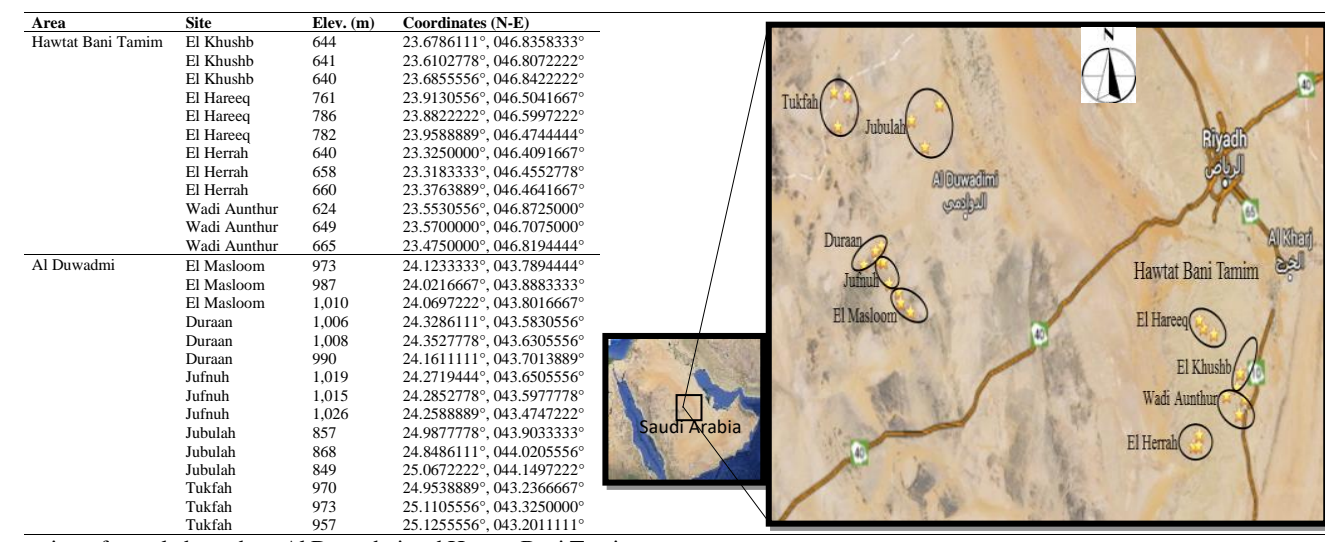

Enlarged map shows sites of sampled stands at Al Duwadmi and Hawtat Bani Tamim

Table 2: Means and standard deviation for Acacia species growth parameters in Hawtat Bani Tamim

\begin{tabular}{|c|c|c|c|c|c|c|c|c|c|c|}
\hline Site & Species & Height (m) & $\mathrm{DBH}(\mathrm{cm})$ & $\begin{array}{l}\text { Crown diameter } \\
(\mathrm{m})\end{array}$ & $\begin{array}{l}\text { Seedlings } \\
(0.1 \mathrm{ha})\end{array}$ & $\begin{array}{l}\text { Saplings }(0.1 \\
\text { ha) }\end{array}$ & $\begin{array}{l}\text { Trees }(0.1 \\
\text { ha) }\end{array}$ & $\begin{array}{l}\text { Intact seeds } \\
(\%)\end{array}$ & $\begin{array}{l}\text { Damaged seeds } \\
(\%)\end{array}$ & Coexisting species \\
\hline El Khushb & $\begin{array}{l}\text { A. raddiana } \\
\text { A. ehrenbergiana }\end{array}$ & $\begin{array}{l}4.80 \pm 0.88 \\
4.65 \pm 0.96\end{array}$ & $\begin{array}{l}10.41 \pm 2.72 \\
4.32 \pm 2.49\end{array}$ & $\begin{array}{l}5.42 \pm 1.67 \\
5.35 \pm 2.12\end{array}$ & $\begin{array}{l}36.0 \pm 8.41 \\
22.0 \pm 7.06\end{array}$ & $\begin{array}{l}3.0 \pm 0.52 \\
0\end{array}$ & $\begin{array}{l}7.0 \pm 1.62 \\
3.0 \pm 0.76\end{array}$ & $\begin{array}{l}77.22 \\
7.69\end{array}$ & $\begin{array}{l}22.78 \\
92.30\end{array}$ & $\begin{array}{l}\text { Lycium shawii } \\
\text { Rhayza stricta }\end{array}$ \\
\hline El Hareeq & $\begin{array}{l}\text { A. raddiana } \\
\text { A. ehrenbergiana } \\
\text { A. tortilis }\end{array}$ & $\begin{array}{l}4.98 \pm 2.70 \\
4.12 \pm 0.41 \\
3.01 \pm 0.97\end{array}$ & $\begin{array}{l}14.96 \pm 6.62 \\
4.00 \pm 1.32 \\
7.67 \pm 2.05\end{array}$ & $\begin{array}{l}5.26 \pm 2.30 \\
2.84 \pm 0.70 \\
4.35 \pm 2.13\end{array}$ & $\begin{array}{l}2.0 \pm 0.93 \\
3.0 \pm 1.01 \\
9.0 \pm 2.54\end{array}$ & $\begin{array}{l}2.0 \pm 0.50 \\
0 \\
3.0 \pm 0.60\end{array}$ & $\begin{array}{l}3.0 \pm 0.98 \\
2.0 \pm 0.35 \\
2.0 \pm 0.56\end{array}$ & $\begin{array}{l}40.90 \\
6.06 \\
39.60\end{array}$ & $\begin{array}{l}59.09 \\
93.94 \\
60.40\end{array}$ & $\begin{array}{l}\text { Cassia italica } \\
\text { Leptadenia } \\
\text { pyrotechnica }\end{array}$ \\
\hline El Herrah & $\begin{array}{l}\text { A. raddiana } \\
\text { A. tortilis }\end{array}$ & $\begin{array}{l}4.62 \pm 1.04 \\
4.20 \pm 1.01\end{array}$ & $\begin{array}{l}10.00 \pm 3.0 \\
9.29 \pm 2.41\end{array}$ & $\begin{array}{l}5.00 \pm 1.46 \\
5.53 \pm 1.67\end{array}$ & $\begin{array}{l}2.0 \pm 0.82 \\
7.0 \pm 2.01\end{array}$ & $\begin{array}{l}3.0 \pm 0.57 \\
4.0 \pm 0.86\end{array}$ & $\begin{array}{l}4.0 \pm 1.63 \\
6.0 \pm 1.98\end{array}$ & $\begin{array}{l}44.57 \\
*\end{array}$ & $\begin{array}{l}55.43 \\
*\end{array}$ & $\begin{array}{l}\text { Rhanterium } \\
\text { epapposum } \\
\text { Lycium shawii }\end{array}$ \\
\hline $\begin{array}{l}\text { Wadi } \\
\text { Aunthur }\end{array}$ & $\begin{array}{l}\text { A. raddiana } \\
\text { A. ehrenbergiana } \\
\text { A. tortilis }\end{array}$ & $\begin{array}{l}5.38 \pm 0.88 \\
4.93 \pm 2.00 \\
5.22 \pm 1.45\end{array}$ & $\begin{array}{l}10.22 \pm 3.07 \\
9.01 \pm 3.03 \\
10.21 \pm 2.37\end{array}$ & $\begin{array}{l}6.44 \pm 2.03 \\
4.94 \pm 1.98 \\
6.38 \pm 1.85\end{array}$ & $\begin{array}{l}25.0 \pm 5.65 \\
7.0 \pm 2.59 \\
11.0 \pm 3.95\end{array}$ & $\begin{array}{l}2.0 \pm 0.67 \\
0 \\
3.0 \pm 0.86\end{array}$ & $\begin{array}{l}3.0 \pm 1.20 \\
3.0 \pm 1.08 \\
6.0 \pm 2.01\end{array}$ & $\begin{array}{l}45.00 \\
8.33 \\
12.50\end{array}$ & $\begin{array}{l}55.00 \\
91.66 \\
87.50\end{array}$ & $\begin{array}{l}\text { Lycium shawii } \\
\text { Cassia italica } \\
\text { Citrullus colocynthis }\end{array}$ \\
\hline
\end{tabular}

*Indicates absence of intact or damaged seeds; DBH. Diameter at breast height

Table 3: Comparison of Acacia growth parameters and seedling density among sites in Hawtat Bani Tamim

\begin{tabular}{|c|c|c|c|c|c|}
\hline Site & Height (m) & $\mathrm{DBH}(\mathrm{cm})$ & Crown diameter $(\mathrm{m})$ & Seedlings (0.1 ha) & Nearby human community \\
\hline El Khushb & $4.74 \pm 0.92^{\text {ba }}$ & $8.34 \pm 2.6^{b}$ & $5.44 \pm 188^{\mathrm{a}}$ & $29.55 \pm 7.35^{\mathrm{a}}$ & Yes \\
\hline El Hareeq & $4.63 \pm 1.40^{\mathrm{ba}}$ & $12.67 \pm 3.30^{\mathrm{a}}$ & $5.07 \pm 1.77^{\mathrm{a}}$ & $4.06 \pm 1.49^{c}$ & No \\
\hline El Herrah & $4.37 \pm 1.02^{\mathrm{b}}$ & $9.58 \pm 2.7^{\mathrm{b}}$ & $5.32 \pm 1.63^{\mathrm{a}}$ & $4.90 \pm 1.41^{\mathrm{c}}$ & No \\
\hline Wadi Aunthur & $5.20 \pm 1.44^{\mathrm{a}}$ & $9.98 \pm 2.8^{b}$ & $6.12 \pm 1.90^{\mathrm{a}}$ & $13.71 \pm 4.06^{\mathrm{b}}$ & No \\
\hline$P<0.05$ & 0.0272 & 0.0333 & 0.3243 & 0.0011 & \\
\hline
\end{tabular}

Values represent means \pm standard deviations

Different letters $(\mathrm{a}, \mathrm{b}, \mathrm{c})$ in the same column indicate significant differences among sites for each variable $(\mathrm{P}<0.05)$;

DBH: Diameter at breast height

$(14.96 \mathrm{~cm})$. El Khushb had the highest $A$. raddiana seedling density (36 per 0.1 ha). The lowest $A$. raddiana seedling densities per 0.1 ha were found at El Hareeq (2) and El Herrah (2). At El Herrah, A. tortilis tree, sapling, and seedling densities were 6,4 , and 7 per 0.1 ha, respectively. The proportions of damaged seeds were $>55 \%$ at all sites except El Khushb (22.78\%).

Table 3 compares Acacia growth parameters and seedling densities among the sites in Hawtat Bani Tamim. There were significant differences in height $(P=0.0272)$, DBH $(P=0.0333)$, and seedlings/0.1 ha $(P=0.0011)$ among Hawtat Bani Tamim sites. Maximum tree height was measured at Wadi Aunther $(5.20 \mathrm{~m})$ but did not significantly differ from those evaluated at El khushb and El Hareeq. Moreover, the maximum tree heights at the latter two sites did not significantly differ from that found at El Herrah. The maximum mean DBH $(12.67 \mathrm{~cm})$ was located at El Hareeq and it significantly differed from those measured at the other sites. Seedling density differed significantly among sites. The highest seedling density per 0.1 ha was recorded at El Khushb (29.55) followed by Wadi Aunthur (13.71).

Table 4 compares the tree growth parameters among Acacia species in Hawtat Bani Tamim. Significant differences in DBH $(P=0.0041)$ and the number of seedlings/0.1 ha $(P=0.0055)$ were observed among Acacia species. A. raddiana had the highest $\mathrm{DBH}$ $(11.56 \mathrm{~cm})$ followed by A. tortilis $(9.64 \mathrm{~cm})$. They did not significantly differ from each other but did significantly differ from A. ehrenbergiana. A. raddiana had the highest average seedling density per 0.1 ha (19.17) followed by $A$. ehrenbergiana (14.90). Both differed significantlly from A. tortilis. A. raddiana, A. ehrenbergiana, and $A$. tortilis accounted for $68.25,19.05$ and $12.70 \%$ of all seedlings, respectively. 
Alshahrani / Intl J Agric Biol, Vol 25, No 5, 2021

Table 4: Comparison of growth parameters among Acacia species in Hawtat Bani Tamim

\begin{tabular}{|c|c|c|c|c|c|c|c|c|c|}
\hline \multirow[t]{2}{*}{ Species } & \multirow{2}{*}{$\begin{array}{l}\text { Height } \\
(\mathrm{m})\end{array}$} & \multirow{2}{*}{$\begin{array}{l}\mathrm{DBH} \\
(\mathrm{cm})\end{array}$} & \multirow{2}{*}{$\begin{array}{l}\text { Crown } \\
\text { diameter (m) }\end{array}$} & \multirow{2}{*}{$\begin{array}{l}\text { Seedlings } \\
(0.1 \mathrm{ha})\end{array}$} & \multirow[t]{2}{*}{ Frequency (\%) } & \multicolumn{4}{|c|}{ Percentage $(\%)$ of individuals in various stage } \\
\hline & & & & & & Seedlings & Saplings & Trees & Regeneration status \\
\hline A. raddiana & $4.95^{\mathrm{a}}$ & $11.56^{\mathrm{a}}$ & $5.84^{\mathrm{a}}$ & $19.17^{\mathrm{a}}$ & 45.53 & 62.77 & 3.65 & 33.57 & Fair \\
\hline A. ehrenbergiana & $4.65^{\mathrm{a}}$ & $5.61^{\mathrm{b}}$ & $4.87^{\mathrm{a}}$ & $14.9^{\mathrm{a}}$ & 16.96 & 45.71 & 0 & 54.29 & Fair \\
\hline A. tortilis & $4.56^{\mathrm{a}}$ & $9.64^{\mathrm{a}}$ & $5.60^{\mathrm{a}}$ & $9.12^{\mathrm{b}}$ & 37.50 & 36.36 & 9.09 & 54.55 & Fair \\
\hline$P<0.05$ & 0.3314 & 0.0041 & 0.2477 & 0.0055 & & & & & \\
\hline
\end{tabular}

Different letters $(\mathrm{a}, \mathrm{b}, \mathrm{c})$ in the same column indicate significant differences among species for each variable $(P<0.05)$

DBH: diameter at breast height

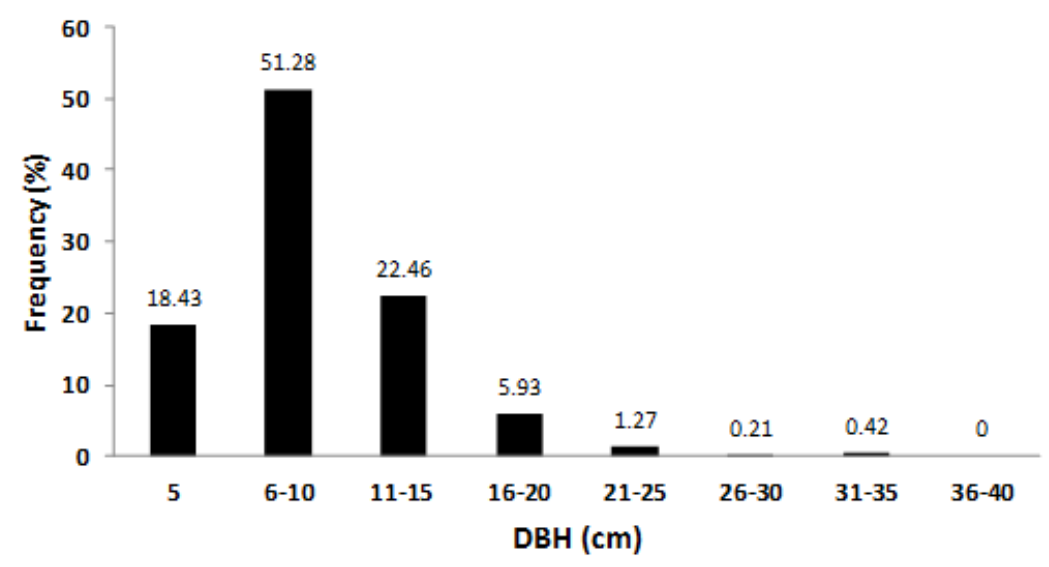

Fig. 1: Acacia species DBH (diameter at breast height) frequency distribution at Hawtat Bani Tamim

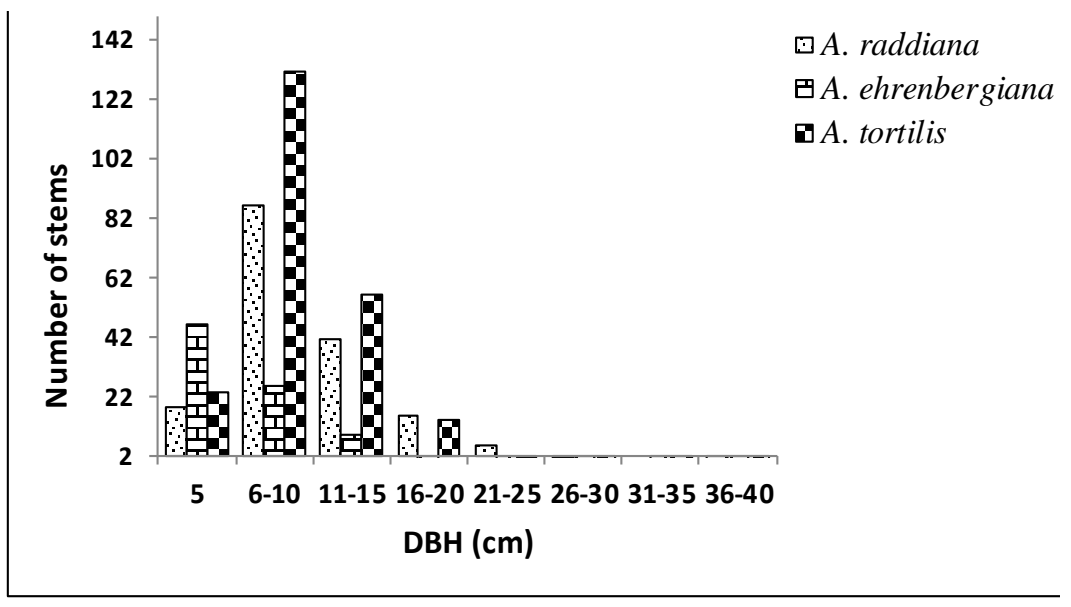

Fig. 2: Acacia species DBH (diameter at breast height) frequency distribution at Hawtat Bani Tamim

The proportions of Acacia seedlings, saplings, and trees varied with species in Hawtat Bani Tamim (Table 4). A. raddiana accounted for $62.77 \%$ of all seedlings but only $3.65 \%$ of all saplings. A. tortilis comprised $9.09 \%$ of all saplings. There were no A. ehrenbrigiana saplings. A. tortilis and A. ehrenbergiana comprised $54.55 \%$ and $54.29 \%$ of all trees, respectively, whereas $33.57 \%$. of the trees were A. raddiana. All species regenerated when the percentages of seedlings were higher than those of the saplings and when the proportions of saplings were lower than those of the trees.

Fig. 1 depicts tree diameter frequency distribution in
Hawtat Bani Tamim. Most DBH were in the 6-10 cm class. About $51.28 \%$ of the total tree diameter frequency was in this class. In contrast, only $\sim 0.42 \%$ of the total tree diameter frequency was in the $31-35 \mathrm{~cm}$ class. A. ehrenbergiana significantly contributed to the $5 \mathrm{~cm}$ diameter class whereas $A$. tortilis and $A$. raddiana figured prominently in the $6-10 \mathrm{~cm}$ and $11-15 \mathrm{~cm}$ diameter classes (Fig. 2). No trees with DBH $>36 \mathrm{~cm}$ were observed. The largest DBH categories, namely, $21-25 \mathrm{~cm}, 26-30 \mathrm{~cm}$ and $31-35 \mathrm{~cm}$, included only $A$. raddiana.

Fig. 3 shows the tree height frequency distributions. The $4.1-5 \mathrm{~m}$ tree height class accounted for $39.29 \%$ of the 
Acacia spp. in Central Saudi Arabia / Intl J Agric Biol, Vol 25, No 5, 2021

Table 5: Means and standard deviation for growth parameters of Acacia species in Al Duwadmi

\begin{tabular}{|c|c|c|c|c|c|c|c|c|c|c|}
\hline Site & Species & Height (m) & $\mathrm{DBH}(\mathrm{cm})$ & $\begin{array}{l}\text { Crown } \\
\text { diameter }(\mathrm{m})\end{array}$ & $\begin{array}{l}\text { Seedlings } \\
\text { (0.1 ha) }\end{array}$ & $\begin{array}{l}\text { Saplings } \\
(0.1 \text { ha })\end{array}$ & $\begin{array}{l}\text { Trees } \\
(0.1 \text { ha })\end{array}$ & $\begin{array}{l}\text { Intact seeds } \\
(\%)\end{array}$ & $\begin{array}{l}\text { Damaged } \\
\text { seeds }(\%)\end{array}$ & Coexisting species \\
\hline$\overline{\mathrm{El}}$ & A. gerrardii & $4.55 \pm 2.39$ & $13.80 \pm 7.94$ & $4.77 \pm 3.63$ & $5.50 \pm 2.82$ & $2.0 \pm 0.46$ & $3.0 \pm 2.00$ & 6.66 & 93.33 & Lycium shawii \\
\hline \multirow[t]{2}{*}{ Masloom } & A. raddiana & $3.83 \pm 0.55$ & $10.76 \pm 3.15$ & $3.02 \pm 0.61$ & $11.0 \pm 8.08$ & $2.0 \pm 0.94$ & $2.0 \pm 0.76$ & 19.44 & 80.55 & Ochradenus baccatus \\
\hline & A. tortilis & $3.85 \pm 2.33$ & $6.83 \pm 3.05$ & $3.12 \pm 1.19$ & $3.0 \pm 1.15$ & $1.0 \pm 0.61$ & $3.0 \pm 1.40$ & 12.50 & 87.50 & \\
\hline Duraan & A. raddiana & $5.55 \pm 1.33$ & $17.90 \pm 6.17$ & $4.9 \pm 1.79$ & $21.0 \pm 3.93$ & $3.0 \pm 1.52$ & $8.0 \pm 0.93$ & 14.42 & 85.57 & $\begin{array}{l}\text { Lycium shawii ; Ziziphus } \\
\text { spina christi }\end{array}$ \\
\hline Jufnuh & A. raddiana & $4.58 \pm 1.26$ & $11.60 \pm 5.04$ & $4.61 \pm 2.01$ & $20.0 \pm 4.21$ & $3.0 \pm 1.14$ & $9.0 \pm 1.30$ & 11.19 & 88.80 & Lycium shawii; Zilla spinosa \\
\hline Tukfah & A. raddiana & $5.23 \pm 1.82$ & $18.27 \pm 8.89$ & $5.68 \pm 2.86$ & $7.15 \pm 3.66$ & $2.0 \pm 1.24$ & $5.0 \pm 1.02$ & 5.47 & 94.52 & Lycium shawii \\
\hline Jubulah & A. gerrardii & $5.76 \pm 1.61$ & $20.57 \pm 4.92$ & $6.55 \pm 0.50$ & $3.33 \pm 0.81$ & $2.0 \pm 0.81$ & $2.0 \pm 057$ & 16.90 & 83.09 & \\
\hline
\end{tabular}

DBH: diameter at breast height

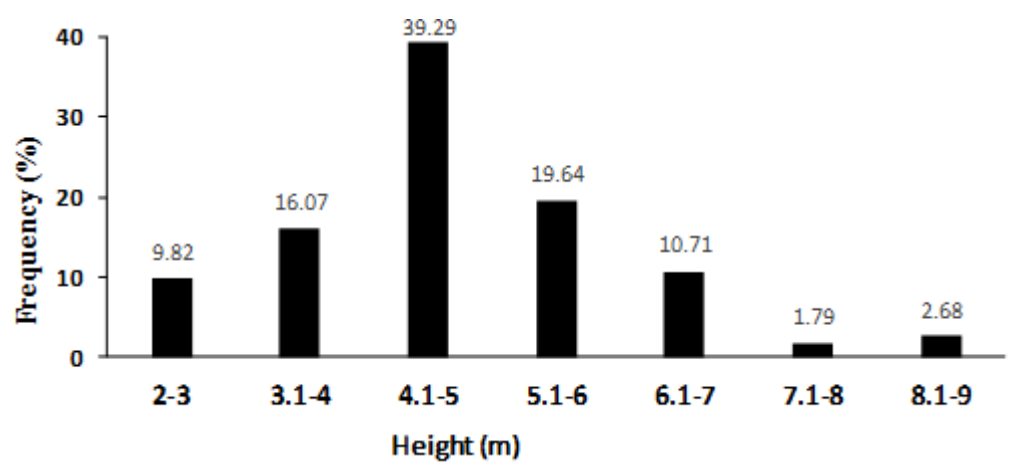

Fig. 3: Acacia species height frequency distribution at Hawtat Bani Tamim

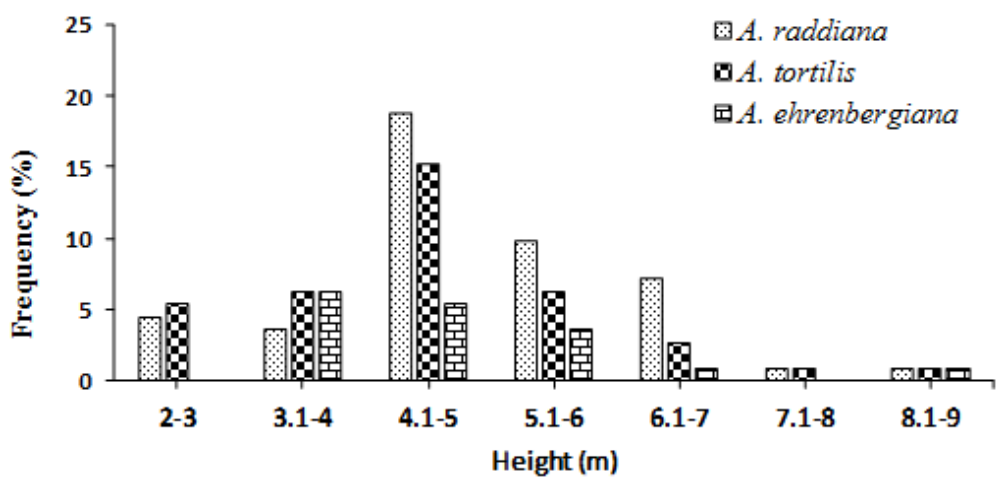

Fig. 4: Acacia species height frequency distribution at Hawtat Bani Tamim

total tree height frequency while the $7.1-8 \mathrm{~m}$ tree class accounted for only $1.79 \%$. All species were represented in the 4.1-5 $\mathrm{m}$ tree height class but it was nonetheless dominated by $A$. raddiana (Fig. 4). There was no $A$. ehrenbergiana in the 2-3 $\mathrm{m}$ or $7.1-8 \mathrm{~m}$ tree height classes.

\section{Acacia growth in Al Duwadmi}

The most commonly occurring Acacia species at $\mathrm{Al}$ Duwadmi was $A$. raddiana $(78.99 \%)$ followed by $A$. gerrardii (11.93\%) and A. tortilis (9.07\%). Table 5 lists the growth parameters for the Acacia species at Al Duwadmi. At El Masloom, the Acacia species were A. gerrardii, A. raddiana, and $A$. tortilis. $A$. gerrardii was the dominant species there. At Jubulah, A. gerrardii and A. raddiana occurred in mixed stands. In Duraan, Jufnuh, and Tukfah, there were mainly pure $A$. raddiana stands. At Jubulah, the maximum height, $\mathrm{DBH}$, and crown diameter for $A$. gerrardii were $5.76 \mathrm{~m}, 20.57 \mathrm{~cm}$, and $6.55 \mathrm{~m}$, respectively. The highest seedling density was 21 for A. raddiana at Duraan whereas the lowest seedling and sapling density/0.1 ha were 3 and 1, respectively, for $A$. tortilis at El Masloom. There were $\leq 3$ saplings/0.1 ha for all species except A. tortilis (1 sapling/0.1 ha). The highest tree density was 9 for $A$. raddiana. The proportion of damaged seeds at Al Duwadmi was $>80 \%$ for all Acacia species (Table 5).

Table 6 compares the tree growth parameters among sites at Al Duwadmi. Significant differences in height $(P=$ $0.0344)$, DBH $(P=0.0002)$, crown diameter $(P=0.0117)$, and seedling density $(P=0.0001)$ were detected among all Al Duwadmi sites. Duraan had the tallest trees $(5.55 \mathrm{~m})$ but their heights did not significantly differ from those of the 
Alshahrani / Intl J Agric Biol, Vol 25, No 5, 2021

Table 6: Comparison of Acacia growth parameters among sites in Al Duwadmi

\begin{tabular}{llllll}
\hline Site & Height $(\mathrm{m})$ & DBH $(\mathrm{cm})$ & Crown diameter $(\mathrm{m})$ & Seedlings $($ per 0.1 ha) & Nearby human community \\
\hline El Masloom & $4.14 \pm 1.75^{\mathrm{b}}$ & $10.14 \pm 5.55^{\mathrm{c}}$ & $3.93 \pm 1.81^{\mathrm{b}}$ & $4.72 \pm 2.35^{\mathrm{c}}$ & No \\
Duraan & $5.55 \pm 1.33^{\mathrm{a}}$ & $17.90 \pm 6.17^{\mathrm{a}}$ & $4.90 \pm 1.75^{\mathrm{ab}}$ & $21.90 \pm 3.75^{\mathrm{a}}$ & No \\
Jufnuh & $4.59 \pm 1.26^{\mathrm{ba}}$ & $11.60 \pm 5.04^{\mathrm{bc}}$ & $4.61 \pm 2.41^{\mathrm{ba}}$ & $20.00 \pm 4.19^{\mathrm{a}}$ & Yes \\
Tukfah & $5.23 \pm 1.82^{\mathrm{ab}}$ & $18.27 \pm 8.89^{\mathrm{a}}$ & $5.68 \pm 2.93^{\mathrm{a}}$ & $7.15 \pm 3.58^{\mathrm{b}}$ & Yes \\
Jubulah & $5.15 \pm 1.78^{\mathrm{ba}}$ & $14.44 \pm 5.11^{\mathrm{ba}}$ & $5.67 \pm 1.66^{\mathrm{a}}$ & $4.96 \pm 1.72^{\mathrm{c}}$ & Yes \\
$P<0.05$ & 0.0344 & 0.0002 & 0.0117 & 0.0001 & \\
\hline Val & &
\end{tabular}

Values represent means \pm standard deviations

Different letters $(\mathrm{a}, \mathrm{b}, \mathrm{c})$ in the same column indicate significant differences among sites for each variable $(P<0.05)$; DBH: diameter at breast height

Table 7: Comparison of growth parameters, seedling density, and population structure among Acacia species in Al Duwadmi

\begin{tabular}{|c|c|c|c|c|c|c|c|c|c|}
\hline \multirow[t]{2}{*}{ Species } & \multirow[t]{2}{*}{ Height (m) } & \multirow[t]{2}{*}{$\mathrm{DBH}(\mathrm{cm})$} & \multirow{2}{*}{$\begin{array}{l}\text { Crown } \\
\text { diameter }(\mathrm{m})\end{array}$} & \multirow{2}{*}{$\begin{array}{l}\text { Seedlings } \\
\text { (0.1 ha) }\end{array}$} & \multirow{2}{*}{$\begin{array}{l}\text { Frequency } \\
(\%)\end{array}$} & \multicolumn{4}{|c|}{ Percentage $(\%)$ of individuals in various stage } \\
\hline & & & & & & Seedlings & Saplings & Trees & Regeneration status \\
\hline A. gerrardii & $5.07 \pm 2.0^{\mathrm{a}}$ & $16.70 \pm 6.4^{\mathrm{a}}$ & $5.56 \pm 2.06^{\mathrm{a}}$ & $4.57 \pm 2.66^{b}$ & 11.93 & 45.45 & 13.64 & 40.91 & Fair \\
\hline A. raddiana & $5.01 \pm 1.38^{\mathrm{a}}$ & $14.53 \pm 5.71^{\mathrm{a}}$ & $5.54 \pm 177^{\mathrm{a}}$ & $14.70 \pm 4.50^{\mathrm{a}}$ & 78.99 & 63.36 & 3.88 & 32.76 & Fair \\
\hline A. tortilis & $3.95 \pm 2.18^{\mathrm{a}}$ & $7.34 \pm 2.41^{\mathrm{b}}$ & $4.92 \pm 1.82^{\mathrm{a}}$ & $3.37 \pm 1.33^{\mathrm{b}}$ & 9.07 & 75.00 & 11.40 & 13.60 & Fair \\
\hline$P<0.05$ & 0.3263 & 0.0042 & 0.3919 & 0.0098 & & & & & \\
\hline
\end{tabular}

Values represent means \pm standard deviations

Different letters $(\mathrm{a}, \mathrm{b}, \mathrm{c})$ in the same column indicate significant differences among species for each variable $(P<0.05)$; DBH: diameter at breast height

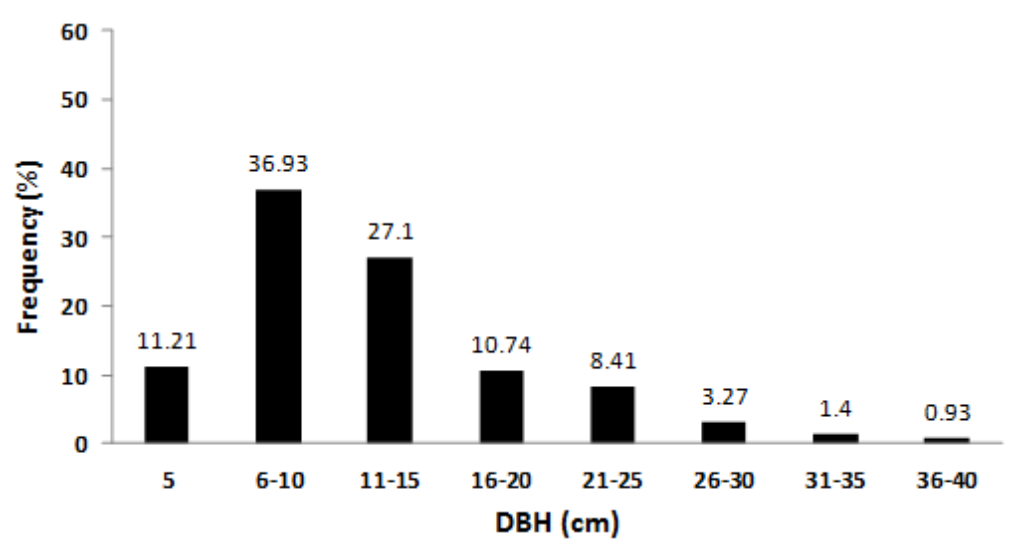

Fig. 5: Acacia species DBH (diameter at breast height) frequency distribution at Al Duwadmi

other sites except for El Masloom (4.14 m). The trees at Tukfah had the highest DBH $(18.27 \mathrm{~cm})$ but this value did not significantly differ from those at Duraan or Jubulah. The crown diameter was greatest at Tukfah $(5.68 \mathrm{~m})$ but did not significantly differ from those at Jubulah or Duraan. Duraan and Jufnuh had 21.90 and 20.0 seedlings per 0.1 ha, respectively.

Table 7 compares the tree growth parameters among Acacia species in Al Duwadmi. Significant differences in DBH $(P=0.0042)$ were observed among Acacia species. $A$. gerrardii had the highest DBH $(16.70 \mathrm{~cm})$ but this value did not significantly differ from that for A. raddiana. Moreover, the DBH for these two species significantly differed from that of $A$. tortilis $(7.34 \mathrm{~cm})$. Significant differences $(P=$ 0.0098) in seedling density were observed among Acacia species. A. raddiana had the highest average seedling density per 0.1 ha (14.7). A. raddiana, A. tortilis and $A$. gerrardii seedlings accounted for 77.36, 17.36, and 5.28 of all Acacia seedlings, respectively. The proportions of seedlings were $75,63.36$ and 45.45 for A. tortilis, A. raddiana, and A. gerrardii, respectively. Saplings accounted for $3.88 \%$ of $A$. raddiana, $11.40 \%$ of $A$. tortilis, and $13.64 \%$ of $A$. gerrardii. Trees accounted for 40.91, 32.76, and $13.6 \%$ of $A$. gerrardii, A. raddiana, and $A$. tortilis, respectively. The regeneration status for Acacia species was fair. The proportion of seedlings was greater than that of the saplings and the percentage of saplings was lower than that of the trees.

Fig. 5 illustrates a tree diameter frequency distribution for Acacia species. Most of the DBH were in the $6-10 \mathrm{~cm}$ and 11-15 cm classes. Together, these classes accounted for $\sim 36.93 \%$ and $\sim 27.1 \%$ of the total $\mathrm{DBH}$ frequency, respectively. Only $0.93 \%$ of the DBH were in the $36-40 \mathrm{~cm}$ class. A. tortilis and A. raddiana were abundant in the 6-10 $\mathrm{cm}$ and $11-15 \mathrm{~cm}$ classes (Fig. 6). Only A. raddiana was in the largest DBH categories including the $26-30 \mathrm{~cm}$ and $31-$ $35 \mathrm{~cm}$ classes. A. gerrardii was abundant in the $6-10 \mathrm{~cm}$ diameter class. The $36-40 \mathrm{~cm} \mathrm{DBH}$ category included only a few $A$. gerrardii and $A$. raddiana individuals (Fig. 6). Fig. 7 shows the tree height frequency distributions. The highest 


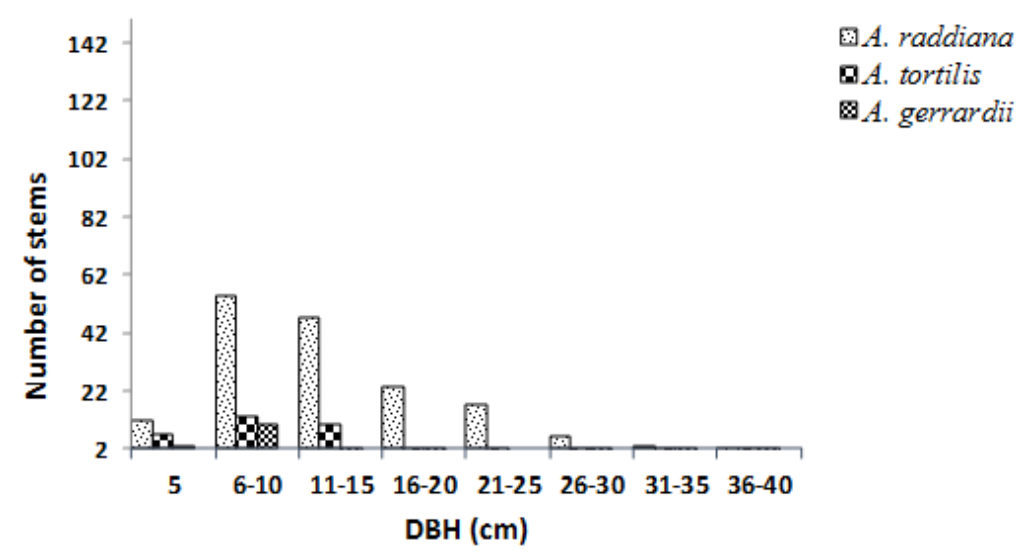

Fig. 6: Acacia species DBH (diameter at breast height) frequency distribution at Al Duwadmi

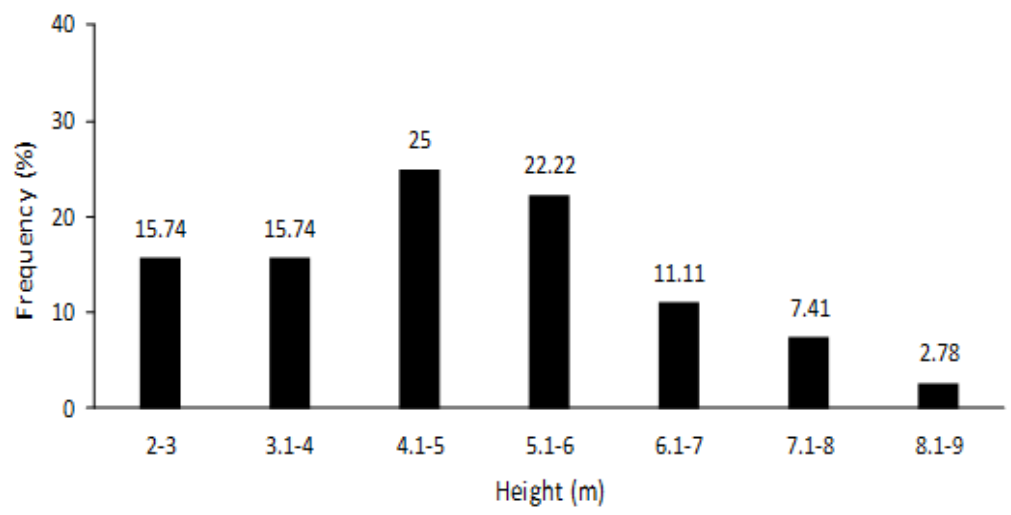

Fig. 7: Acacia species height frequency distribution at Al Duwadmi

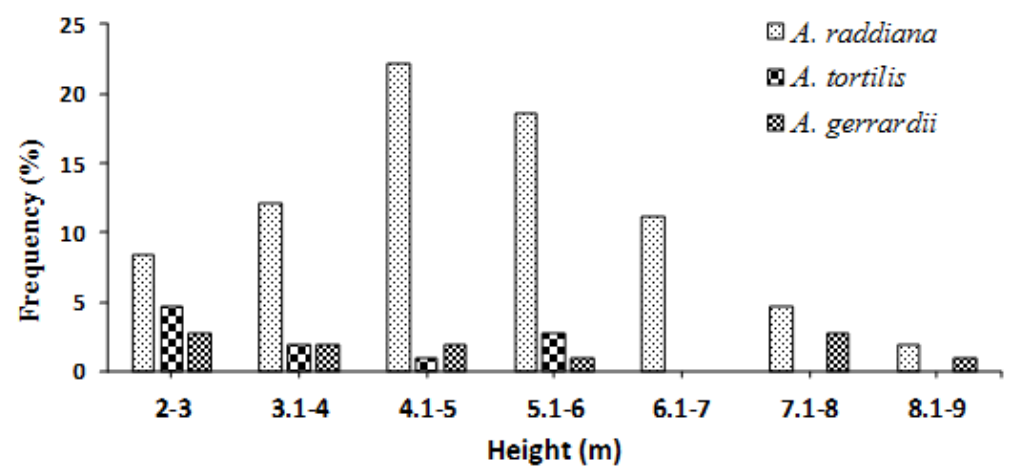

Fig. 8: Acacia species height frequency distribution at Al Duwadmi

tree height frequencies were 25 and $22.22 \%$ in the $4.1-5 \mathrm{~m}$ and 5.1-6 m classes, respectively. The lowest tree height frequency was only $2.78 \%$ in the $8.1-9 \mathrm{~m}$ class (Fig. 7). A. raddiana dominated all height classes (Fig. 8). There were no $A$. tortilis trees in the $6.1-7 \mathrm{~m}, 7.1-8 \mathrm{~m}$, or $8.1-9 \mathrm{~m}$ height classes and no $A$. gerrardii trees in the $6.1-7 \mathrm{~m}$ height class.

\section{Discussion}

In this study, there were comparatively few large-diameter
(>35 cm) Acacia trees. The abundance of trees with small $\mathrm{DBH}$ and the gradual decreases in height and DBH for the higher classes indicate that mature large-diameter trees had already been cut down. Wickens et al. (1995) reported that A. raddiana in Tunisia reached a diameter of $40 \mathrm{~cm}$ in $125 \mathrm{y}$ and $90 \mathrm{~cm}$ in $250-300 \mathrm{y}$. The slow growth of the genus Acacia is an adaptation to its native arid environments (Elfadl 2013). For this reason, Acacia woodlands must be conserved. The frequencies of trees with $\mathrm{DBH}>25 \mathrm{~cm}$ were only $0.5 \%$ in Hawtat Bani Tamim and $3.27 \%$ in $\mathrm{Al}$ Duwadmi. Atsbha et al. (2019) explained the low frequency 


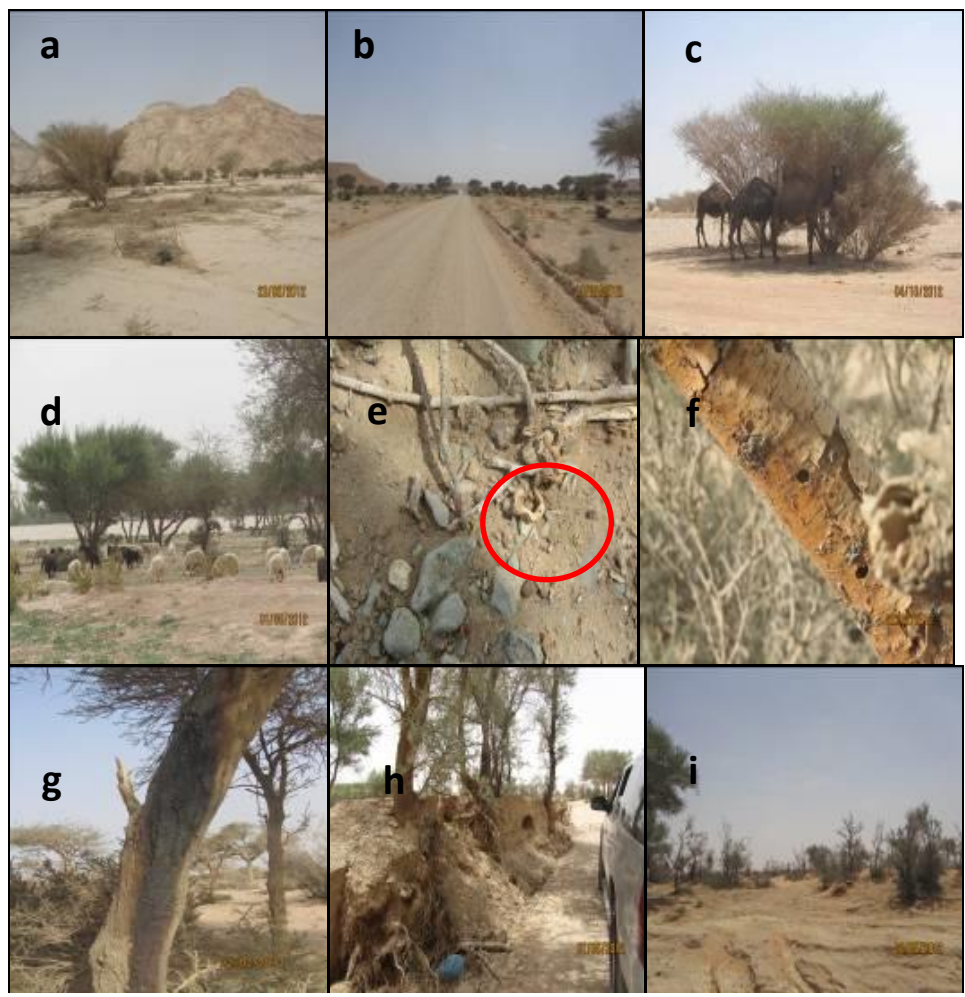

Fig. 9: Photographs showing hazards to Acacia species in central Saudi Arabia; (a) cutting, (b) road building, (c and d) grazing by camels and sheep, (e) seed predation, (f) insects, (g) diseases, (h) soil erosion, and (i) drought

(2.58\%) of large-diameter (> $25.1 \mathrm{~cm}$ ) trees in Ethiopia by illegal local cutting for construction materials and fuelwood. Several factors such as human activities, insects, disease, seed predation, grazing, and drought may have impeded Acacia growth and regeneration (Fig. 9).

In Saudi Arabia, high local demands for fuelwood have hindered vegetation cover by woody species such as $A$. tortilis which has high thermal value (20.45 $\mathrm{MJ} \mathrm{kg}^{-1}$ ) (Nasser and Aref 2014). This Acacia species is preferable fuelwood for that nation (Al-Abdulkader et al. 2004). The frequent harvest of $A$. tortilis for fuelwood explains the low numbers of stems with diameters $<15 \mathrm{~cm}$ and the lack of diameter classes $>15 \mathrm{~cm}$ at $\mathrm{Al}$ Duwadmi. The lack of coppice regeneration was evident in the two areas surveyed. Despite the important of coppicing as a management practice, it is not applied in all Acacia woodlands. Coppice management is very efficient because it promotes regeneration and shortens regrowth time (Spinelli et al. 2017). In Acacia woodlands, single-stem species such as $A$. gerrardii and $A$. raddiana or those with multiple stems such as $A$. tortilis and A. ehrenberigiana are cut $5-10 \mathrm{~cm}$ above ground. The ability of cut trees to sprout new branches depends on biotic and abiotic factors such as cutting height and stem size (Khan and Tripathi 1986; Tiwari and Das 2010), stump diameter (Shackleton 2001), and soil moisture (Ferm and Kauppi 1990; Liu and Dickmann 1996). Mayo et al. (2016) demonstrated that resprouting is both water- and nutrient-limited in cut trees and resource addition does not replenish stem carbon storage. Soil with high moisture content increases sprouting vigor and the transfer and supply of phytohormones such as auxins, cytokinins, and gibberellins (Ferm and Kauppi 1990). However, these responses are absent in soils with very low moisture (Liu and Dickmann 1996).

The soil seed bank comprises the viable seeds in the soil (Baker 1989). However, the high seedling density at El Khushb reflected the high percentage of intact seeds $(>77 \%)$. Natural regeneration of vegetation at disturbed sites depends on soil seed bank recruitment. Nevertheless, recruitment may be limited when insufficient seeds are available. In the two areas studied here, the soil was subjected to frequent vehicle passage and that may lead to damage seeds and the new seedlings. Off-road vehicle driving in the Saudi Arabia rangelands contributed to soil compaction and the soil bulk density was 38\% higher under the motor vehicle tracks than that of undisturbed soils (Assaeed et al. 2018). Compacted soil exposes seeds to predators, inhibits seed germination, and impedes seedling growth (Kozlowski 1999). Stelli (2012) stated that the seed bank density of certain Acacia species significantly increased with decreasing soil compaction.

Seeds are the primary source of Acacia regeneration. In Saudi Arabia, mature Acacia pods are scarcely available as camels consume the unripe green seedpods and/or the seeds themselves. There are $\sim 848,000$ camels in Saudi Arabia (Abdallah and Faye 2012). Camels may be 
endozoochorous dispersal agents in Acacia woodlands but at the same time camels are large herbivores that consume unsplit Acacia pods that retain moisture and nutrients. After successful establishment, however, the seedlings are more palatable to camels than the mature plants. The high percentage of infested seeds observed in the present study was consistent with the findings of Ward et al. (2010). They reported that $97 \%$ of all $A$. raddiana and A. tortilis seeds sampled were infested with bruchid beetles (Bruchidius). Variations among species in terms of percentage of infected seeds may reflect their relative ability to produce defensive compounds. Acacia seeds accumulate non-protein amino acids as secondary metabolites (Evans et al. 1993) that could deter predation and may even be toxic to insects (Romeo 1998). Endosperm weight may influence insect predator seed selection (Alshahrani 2018).

Protection of Acacia woodlands is the most effective way to restore vegetative cover. Traoré et al. (2008) observed good Acacia regeneration in Burkina Faso in protected areas of livestock grazing and poor regeneration in areas with high human impact. Ten-year protection of some Acacia trees by restricted planting in Abéché, Chad improved total land cover and enhanced tree height and density (Malagnoux et al. 2007).

The sparsity of Acacia saplings in the study areas reflects the shortage of seedlings in transition to the sapling stage caused by drought and/or grazing. In Saudi Arabia, the average annual rainfall is $114 \mathrm{~mm}$ (DeNicola et al. 2015) and minimizing the risk of severe drought may have a positive impact on seedling growth and tree reproduction where water harvesting can sustain seedling, sapling, and tree growth. The high seedling density observed at El Khushb in Hawtat Bani Tamim (29 seedlings per 0.1 ha) was attributed to unplanned water harvesting in small, random bunds near a human community. In the Thal Desert of Pakistan, using a sloping catchment technique enhanced water supply and increased the maximum average height of A. tortilis to $155 \mathrm{~cm}$ within $1.5 \mathrm{y}$ (Sheikh et al. 1984). Saoub et al. (2011) found that implementing water harvesting and protecting plants from grazing for $3-4 \mathrm{y}$ increased plant biomass and the number of species in the Badia of Jordan. To overcome water problems in Saudi Arabia, treated wastewater can be used to irrigate seedlings in nurseries and plantations. Wastewater improves essential nutrient availability in the deficient soils of arid regions (Tabari and Salehi 2009).

\section{Conclusion}

Acacia species in two study areas of central Saudi Arabia comprised A. raddiana, A. tortilis, A. ehrenbergiana and $A$. gerrardii. A. raddiana was the dominant species at all sites in both areas. The gradual decline in the number of trees in the high-DBH categories may be due to selective removal of the wider trees. The regeneration status for the Acacia species in both areas was fair. There were more seedlings than saplings and fewer saplings than trees. These data may serve as a baseline for future comparison studies to monitor local and regional changes in Acacia species. Thrust may be to design sustainable silvicultural systems for Acacia woodlands. Local communities should be designated to monitor and maintain the regeneration, growth, and protection of Acacia woodlands. To promote stress resilient woodlands, it is necessary to protect existing trees, apply coppicing, use water-harvesting techniques, and plant nursery-grown seedlings inoculated with root microbial strains.

\section{Acknowledgments}

The author thanks the Deanship of Scientific Research, King Saud University, Saudi Arabia for supporting this work.

\section{Author Contributions}

The author collected and analyzed the data and wrote the paper.

\section{Conflict of Interest}

The author declares no conflict of interest of any sort.

\section{Data Availability}

The data relevant to the paper are available with the author and will be available on reasonable request.

\section{Ethics Approval}

Not applicable

\section{References}

Abdallah HR, B Faye (2012). Phenotypic classification of Saudi Arabian camel (Camelus dromedarius) by their body measurements. Emir J Food Agric 24:272-280

Al-Abdulkader AM, NS Al-Khalifa, TH Nasroon, AH Al Farhan, TM AlAbbasi (2004). The present status of samor firewood markets in Saudi Arabia and its effects on vegetation cover. J King Saud Univ Agric Sci 17:45-60

Al-Rowaily SL, MI El-Bana, FA Al-Dujain (2012). Changes in vegetation composition and diversity in relation to morphometry, soil and grazing on a hyper-arid watershed in the central Saudi Arabia. Catena 97:41-49

Al-Rowaily SL, AM Assaeed, SA Al-Khateeb, AA Al-Qarawi, FS Al Arif (2018). Vegetation and condition of arid rangeland ecosystem in Central Saudi Arabia. Saudi J Biol Sci 25:1022-1026

Alshaharani TS, ND Shetta (2015). Phenotypic and biochemical characterization of root nodule bacteria naturally associated with woody tree legumes in Saudi Arabia. J Environ Biol 36:363-370

Alshahrani TS (2018). Seed traits of five Acacia species in two areas of Saudi Arabia. Pak J Bot 50:1531-1538

Assaeed AM, SL Al-Rowaily, MI El-Bana, AA Abood, BA Dar, AK Hegazy (2018). Impact of off-road vehicles on soil and vegetation in a desert rangeland in Saudi Arabia. Saudi J Biol Sci 26:11871193 
Atsbha T, AB Desta, T Zewdu (2019). Woody species diversity, population structure, and regeneration status in the Gra-Kahsu natural vegetation, southern Tigray of Ethiopia. Heliyon 5; Article $\mathrm{e} 01220$

Baker H (1989). Some aspects of the natural history of seed banks. In: Ecology of Soil Seed Banks, pp:9-21. Leck M, V Parker and R Simpson (eds.). Academic Press, San Diego, California, USA

Chaudhary SA (1999). Flora of the Kingdom of Saudi Arabia. Illustrated, Ministry of Agriculture \& Water, National Herbarium. National Agriculture and Water Research Center, Riyadh, Saudi Arabia

Collenette S (1999). Wildflowers of Saudi Arabia. National Commission for Wildlife Conservation and Development (NCWCD), Riyadh, Saudi Arabia

De Boever M (2015). Influence of Acacia Trees on Topsoil physicochemical properties and water balance in arid soils. $P h D$ thesis, Dept of Soil Manage, Ghent University, Ghent, Belgium

DeNicola E, OS Aburizaiza, A Siddique, H Khwaja (2015). Climate change and water scarcity: The case of Saudi Arabia. Ann Glob Heal $81: 342-352$

Elfadl AM (2013). Growth performance and physiological characteristics of seedlings of six tropical dry land forest tree species in the Sudan. $J$ Nat Res Environ Stud 1-2:25-33

Evans CS, AJ Shah, MW Adlard, RA Lourdes (1993). Non-protein amino acids in seeds of neotropical species of Acacia. Phytochemistry $32: 123-126$

FAO (2011). Assessing Forest Degradation: Towards the Development of Globally Applicable Guidelines, p:109. Forest Resources Assessment, FAO, Rome, Italy

Ferm A, A Kauppi (1990). Coppicing as a means for increasing hardwood biomass production. Biomass 22:107-121

Ghazoul J, Z Burivalova, J Garcia-Ulloa, LA King (2015). Conceptualizing forest degradation. Trends Ecol Evol 30:622-632

Khan ML, RS Tripathi (1986). Tree regeneration in a disturbed sub-tropical: Wet hill forest of north-east India: Effect of stump diameter and height on sprouting of four tree species. For Ecol Manage 17:199 209

Khumbongmayum AD, ML Khan, RS Tripathi (2006). Biodiversity conservation in sacred groves of Manipur, northeast India: Population structure and regeneration status of woody species. Biodivers Conserv 15:2439-2456

Kozlowski TT (1999). Soil compaction and growth of woody plants. Scand. J For Res 14:596-619

Liu Z, DI Dickmann (1996). Effects of water and nitrogen interaction on net photosynthesis, stomatal conductance, and water-use efficiency in two hybrid poplar clones. Physiol Plantarum 97:507-512

Malagnoux M, EH Sène, N Atzmon (2007). Forests, trees and water in arid lands: A delicate balance. Unasylva 58:24-32

Mayo H, MC Scholes, W Twine (2016). Effects of water and nutrient addition on the coppice growth response of cut Terminalia sericea. Koedoe 58; Article a1371

Munzbergova Z, D Ward (2002). Acacia trees as keystone species in Negev desert ecosystems. J Veg Sci 13:227-236

Nasser RA, IM Aref (2014). Fuelwood characteristics of six acacia species growing wild in the Southwest of Saudi Arabia as affected by geographical location. BioResources 9:1212-1224
Noumi Z, B Touzardb, R Michalet, M Chaieb (2010). The effects of browsing on the structure of Acacia tortilis (Forssk.) Hayne ssp. raddiana (Savi) Brenan along a gradient of water availability in arid zones of Tunisia. J Arid Environ 6:625-631

Nyland RD (2017). Exploitative cutting and stand rehabilitation. In: Silviculture. Concepts and Applications. Waveland Press, Inc., Long Grove, Illinois, USA

Puri L, H Meilby, S Rayamajhi, Y Timilsina, N Gautam, R Subedi, H Larsen (2013). Growth and volume based on permanent sample plots in forests managed by communities. Banko Janakari 22:11-18

Romeo JT (1998). Functional multiplicity among nonprotein amino acids in mimosoid legumes: A case against redundancy. Ecoscience 5:287294

Ross Z, J Burt (2015). Unusual canopy architecture in the umbrella thorn acacia, Vachellia tortilis (Acacia tortilis), in the United Arab Emirates. J Arid Environ 115:62-65

Saoub HM, R Al Tabini, K Al Khalidi, JY Ayad (2011). Effect of three water harvesting techniques on forage shrub and natural vegetation in the Badia of Jordan. Intl J Bot 7:230-236

Shackleton CM (2001). Managing regrowth of an indigenous savanna tree species (Terminalia sericea) for fuelwood: The influence of stump dimensions and post-harvest coppice pruning. Biomass Bioener 20:261-270

Sheikh I, BH Shah, A Aleem (1984). Effect of rainwater harvesting methods on the establishment of tree species. For Ecol Manage 8:257-263

Spinelli R, N Magagnotti, J Schweie (2017). Trends and perspectives in coppice harvesting. Croat J For Eng 38:219-230

Stelli SA (2012). Seed fate and density of soil seed banks of four Acacia species in the Kruger National Park, South Africa, Master's Thesis Faculty of Science, University of the Witwatersrand, Johannesburg, South Africa

Tabari M, A Salehi (2009). The use of municipal wastewater in afforestation: Effects on soil properties and Eldar pine trees. Pol J Environ Stud 18:1113-1121

Thompson ID, MR Guariguata, K Okabe, C Bahamondez, R Nasi, V Heymell, C Sabogal (2013). An operational framework for defining and monitoring forest degradation. Ecol Soc 18; Article 20

Tiwari RK, K Das (2010). Effect of stem cuttings and hormonal pretreatment on propagation of Embelia tsjeriam and Caesalpinia bonduc, two important medicinal plant species. J Med Plant Res 4:1577-1583

Traoré S, O Kaboré, JM Rasolodimby, L Thiombiano, S Guinko (2008). Impact of protected areas and land use on regeneration of acacia woodland's in eastern Burkina Faso. Flora Veg. Sudano-Sambes 11:17-24

Ward D, I Musli, K Or, T Gbenro, O Skutelsky (2010). Bruchid seed infestation and development time in three host species of Acacia Zool Middle East 51:95-103

Wickens GE, AG Seif-El-Din, G Sita, I Nahal (1995). Role of Acacia Species in the Rural Economy of Dry Africa and the Near East. FAO Conservation Guide 27, Rome, Italy

Zahran HH (1999). Rhizobium-legume symbiosis and nitrogen fixation under severe conditions and in an arid climate. Microbiol Mol Biol $\operatorname{Rev}$ 63:968-989 